\title{
DECLARATION TOWARD A GLOBAL ETHIC OF THE PARLIAMENT OF THE WORLD'S RELIGIONS AND BUILDING WORLD PEACE
}

\author{
H. Sholihan \\ IAIN Walisongo Semarang \\ Sholihan_ham@yahoo.com
}

Tulisan ini membahas Etika Global Deklarasi Parlemen Agama-agama Dunia dan signifikansinya bagi penciptaan dunia yang damai, dalam pengertiannya sebagai negative peace ataupun positive peace. Ada beberapa nilai yang harus ada dalam dunia yang damai, yaitu: non-kekerasan, kesejahteraan ekonomi, keadilan sosial, keseimbangan ekologis, dan kesetaraan, khususnya keseteraan gender. Nilainilai ini pulalah yang dipromosikan oleh Deklarasi Etika Global yaitu, komitmen pada budaya non-kekerasan dan hormat pada kehidupan, komitmen pada budaya solidaritas dan tata ekonomi yang adil, komitmen pada budaya toleransi dan hidup yang benar, dan komitmen pada budaya persamaan hak dan kemitrasejajaran antara laki-laki dan perempuan. Dengan demikian jelaslah signifikansi deklarasi etika global bagi upaya penciptaan dunia yang damai.

Kata Kunci: Etika Global, World Peace, Negative Peace, Positive Peace.

\section{INTRODUCTION}

The era in which we are living today called postmodern. As a cultural-intellectual movement, postmodern it self raised on 1960s, starting in architect and broadened to another disciplines like literature, social science, life style, philosophy, and even religion. Postmodernism born in Europe and disseminate to America, and then to all over the world like unbearable water 
flood. Principally, this movement criticize modernism "project"1 which is seen as failed in reaching its goal. ${ }^{2}$

Modernism appeared in history as a progressive power which promise the freedom of human beings of backwardness and irrationality restrain. ${ }^{3}$ The project of modernism is not only failed in reaching its goal, but worse because it generated negative impact on human life as well as nature in general, although there are some positive points that must be recognized. Hans Kung described this well when he stated that modernism born sciences but without any wise; technology but without any spiritual power, industry, but without any ecology; and democracy, but without any morality. ${ }^{4}$

Such was the case; the world recently indicated by the discourses on "global crisis". Nowadays human being is getting more realized that all crises in the world are not only caused by material basis, but even more by transcendental causes: the reason of human's view on this nature. Present modern world has no more spiritual horizon. ${ }^{5}$ Even Schumacher more explicitly stated that the failures of modernism project indicated by such so many crises are caused by no religion along within it. ${ }^{6}$

As being discussed above, postmodernism spread so quickly to all aspects of life, included religion. Agree with the epistemological characteristics of postmodernism that would embrace all the narration existed, included religion, both as the trend of contemporary history and as the part of epistemological legitimation in finding truth after a long time become the forgotten truth in modern thought paradigm. As the historical trend, postmodernism showed many crises that are caused by the movement of modernism that forgot a very important dimension in human life: the spiritual dimension. Therefore, to leave from the crises circle, human being tried to go back to spiritual wise existing in all authentic religions. ${ }^{7}$ That is why so many scholars forecasted that twenty first century which is the first year of third millennium in human civilization is the century of religious revival. Among the scholars mentioned are Soejatmoko, ${ }^{8}$ Andre Malraux, ${ }^{9}$ John Naisbitt and Patricia Aburdune. ${ }^{10}$

As such, there is a great expectation on religion to solve the crises raised by modernism project. Viewing this phenomenon, there is a question followed: what kind of religious format that is expected to solve crises? This question is needed to ask because in line to the great expectation, there is also a pessimistic tone. This pessimistic tone generated by the scholars on religious studies see the fact either, that in internal level of religious community themselves, Catholics, Protestantism, Islam, Hinduism, Buddhism, and other religions there is still occupation in the problem of 
truth claim. Thus, religion is not only far reaching to solve the world problems but even more can generate inter religious conflict, ${ }^{11}$ which constituted a specific problem not least serious than the other problems that the human beings faced. In fact, empirically we can see the world map nowadays is indicated by many kinds of religious conflicts. Being not the only one factor, but clearly religious considerations in conflicts as well as in its escalation take a great part. ${ }^{12}$ Take some examples: conflict in North Ireland between Catholics and Protestantism, conflict in Palestine which involved within it the Jews, Moslem, and Christian, conflict in India between Hinduism and Moslem, in Philipine between Catholics and Muslim, and in Indonesian context - exactly in Moluccas - is between Moslem and Christian. Once the religious format stressed more on truth claim -and thus so exclusive and not dialogic - consequently it is so hard to lay the great expectation on religion, so the inclusive and dialogic model seemed to be more hopeful for making the expectations as reality. ${ }^{13}$

It is in this context, The Parliament of the World's Religions in its congress in Chicago on 28 August through 4 September 1993 announced Declaration toward a Global Ethic. This declaration based on the assumtion that the world and religions changed. World now is united, polycentric, multi-cultural, and multi-religious. In such a context, the only way for interreligious relations is "inter-religious brotherhood". Religions with high ethic value must commonly involve in the dialogue on critical problems of the future of human life and destiny. ${ }^{14}$

The Parliament of the World's Religions believed that ethic values within religions can be applied for resolving global crisis which this world faced and threatened the future of human kinds. The ethic values them selves are enable to solve all the so complicated world problems, but they can become moral basis for a better individual and global order. ${ }^{15}$ That is why the Parliament explicitly stated that "No better global order without a global ethic". 16

This paper will discuss about A Global Ethic of The Parliament of the World's Religions Declaration and its significance for building world peace. Comprehensively, the discussion in this paper will consist of the background and principles of a global ethic, significance of a global ethic for building world peace, and critiques and possible solutions as closing remarks.

\section{BACKGROUND AND PRINCIPLES OF A GLOBAL ETHIC}


As mentioned before, a global ethic is principles declared by The Parliament of the World's Religions on its congress in Chicago, United State of America, 28 August to 4 September 1993, completely named Declaration toward a Global Ethic. The congress intended to be the centenary celebration of the 1893 The Parliament of the World's Religions. ${ }^{17}$ Therefore, before describing a global ethic, it is need to describe The Parliament of the World's Religions it self as institution declared it, and the background and process of the declaration.

The Parliament of the World's Religions emerged at the same time with the World Columbian Exposition in Chicago in autumn 1983, held to celebrate the four hundredth anniversary of the discovery of America by Christopher Columbus. Here was a demonstration of economics, science, and industry on a world scale. There were congresses in all areas of cultures from the women's question to social reform, from medicine through the arts, and religion. For the department of religion, it held a congress of representatives of great religions. ${ }^{18}$ It was called by the first The Parliament of the World's Religions congress, that was celebrated the centenary with the same congress on 1993, then called by the second The Parliament of the World's Religions congress. ${ }^{19}$

It is need to be explained here related to word of "Parliament" in The Parliament of the World's Religions. The "Parliament" was an attempt to express two things: (1) the representatives of the world religions gather at the same time in one place, stand side by side with equal rights, and communicate with respect for one another. This de facto does away with any claim to superiority on the part of one religion over another, at least for the time of the Parliament. (2) The representatives of religions come from the grass roots of their membership. They are not members of the hierarchies of the religions, official delegations sent by their leaders or Parliaments. They represent their religions each in an individual way. So from the beginning The Parliament of the World's Religion had the character not of an institution but of a movement, and this guaranteed its dynamic and variety. From the beginning, it did not have the character of a statuary diplomatic exchange, but one of spontaneous human encounter. ${ }^{20}$

The emergence of The Declaration toward a Global Ethic was not suddenly, but through a long process. Hans Kung, bright and controversial Catholic thinker, was the man who played the big role in emerging of the declaration. He was the initiator and formulator of the basic thought of a global ethic, which later was adopted by congress of The Parliament of the World's Religions. In his article under the title "The History, Significance 
and Method of the Declaration toward a Global Ethic", Hans Kung explained, that his thought about a global ethic has been emerged since 1989, when in the first time he did contact with many groups have interest to the centenary celebration of The Parliament of the World's Religions. Since that, he began to write his thoughts related to many issues around a global ethic and presented to many circles in many occasions. ${ }^{21}$

On 14 July 1992 the first draft of the declaration was ready and immediately sent to the experts for comments and corrections. Without exception it met with great approval; its basic structure remained unchanged, but it was considerably improved by numerous detailed suggestions. After being revised many times based on some suggestions of experts from some circles, finally a global ethic which has been formulated by Hans Kung was adopted by The Parliament of the World's Religions and was declared in the congress in Chicago, 28 August to 4 September 1993.

Although a global ethic formerly was, Hans Kung's thought, because it was adopted by The Parliament of the World's Religions, so it could be said that a global ethic has been or become inter religion shared property, and has been become part of the conscious development for religions in the world. This thought was adopted as a something like an ethical binder for global communication among religions in this world.

In the context of such a multi-cultural and multi-religious world living, the only way for inter-religious communication is "religious brotherhood". Religions with a high ethic value must commonly involve them selves into the dialog on critical problems in human life and dignity in the future. ${ }^{22}$

As discussed above, besides generating some positive points, modernism also implying negative implication. Human beings now effected by fundamental global crises: economy, ecology, and politic, ${ }^{23}$ so the usual terms is global crises. Global crises attacking human beings surely will threaten its future. For that reason the Parliament of the World's Religions realized the need of global responsibility in recovering global jeopardy, by realizing a better new global order In order to realize the better new order, it is needed a global ethical basis. the Parliament was sure that "no new global order without a new a global ethic". ${ }^{24}$ Therefore, a global ethic has dual purposes: to reach peace among religions, and to overcome global crises. ${ }^{25}$ Peace among religions constitutes an important thing, because like Hans Kung stated, "No world peace without religious peace". 26 
Thus, a global ethic declared by the Parliament of the World's Religions constitutes an ethic based on ethics value of religions in the world. Nevertheless, a global ethic is not a single unified religion beyond all existing religions, and certainly not the domination of one religion over all others. A global ethic as the Parliament of World Religions meant is "a fundamental consensus on binding values, irrevocable standards, and personal attitudes". ${ }^{27}$ Without such a basic consensus in ethic, The Parliament of the World's Religions was sure, every community sooner or later will be threatened by chaos or dictatorship, and individual will despair. ${ }^{28}$

The problem is: How can the concencus realized? This question needed to be asked, because in fact every religion has different theoretical and conceptual frameworks in ethics. How to make the theoretical and conceptual frameworks of religions will not contradict to the concencus and commitment in a global ethic?

Related to the question, Hans Kung stated that, "A good and true religion will not contradict to human value, but even make humanity perfect. In this point, he state humanum as truth criteria of religion. ${ }^{29}$ Therefore, it can be said that humanistic dimension of religions will make common consensus and commitment of religions possible to implement in global ethic; and in fact a global ethic is humanistical. A global ethic stated the fundamental requirement, "every human being must be treated humanely". 30

In addition to its humanistic characteristic, declaration of a global ethic asked for some requirements, both stated negatively and positively. The negative points here are some points which may not be in the declaration of a global ethic. They are, firstly, no reduplication of the Declaration on Human Right; secondly, no political declaration; thirdly, no casuistic moral sermon; fourthly, no philosophical treatise; and fifthly, no enthusiastic religious proclamation. ${ }^{31}$ While the positive points which must be in a global ethic are, firstly, must penetrate to a deeper ethical level; secondly, must be capable of securing a consensus; thirdly, must be self critical; fourthly, must be related to reality; fifthly, must be generally comprehensible; and sixthly, must have a religious foundation. ${ }^{32}$

Based on above terms of reference above the Parliament stated four ethical guideline in its declaration, first, commitment to a culture of nonviolence and respect for life; second, commitment to a culture of solidarity and a just economic order; third, commitment to a culture of tolerance and a life of truthfully; and fourth, commitment to a culture of equal rights and partnership between men and women. ${ }^{33}$

Those described above are some main ideas of declaration toward a 
global ethic, which constitutes moral concencus among religions. It is needed to emphasize here that a global ethic is not a complete system for all religion adherents, but only normative value, a minimal common attitudes. Consequently, at the end of its declaration, the Parliament conveyed some points related to the declaration that they announced to. Firstly, of the universal concensus on the ethics questions contradicted will be difficult to attain. However, the Parliament expected that suitable solution should be attainable in the spirit of fundamental principles jointly developed in the declaration. Secondly, in many areas of life, a new consciousness on ethical responsibility has already arisen. Therefore, the Parliament would be pleased if as many as possible national or international professional organizations, such as those for physicians, scientists, business people, journalists, and politicians, would compose up to date codes of ethics. Thirdly, more than that, the Parliament asked believer community to formulate a very specific ethic for themselves. All of these efforts will deepen and specify the global ethic which had been commonly settled. ${ }^{34}$

\section{GLOBAL ETHIC: ITS SIGNIFICANCE FOR BUILDING WORLD PEACE}

A global ethic is not intent to reduce religions into level of merely moral or humanity. A global ethic was not for denying specific characteristic of religions and therefore it must not threaten the uniqueness of each religion. A global ethic as a common moral concencus among religious adherents must be observed adversely, as cooperative and critical step for formulating global responsibility. Treating the global fundamental crises that this world facing, which in turn will threat the future of human being, religions being asked their responsibility, not only individually but also commonly.

Among much fundamental crises this world facing, which was very concerned by the Parliament, as described above, is the development of "culture" of violence rising in conflict and war, both with political and religious back ground. The road of human history seemed to be colored by conflict and war. According to Djoko Suryo, Professor of History in Gadjah Mada University Yogyakarta, the symptom of violence, barbarity, cruelty, and all actions of inhumanity which come out in human life, which essentially has been old, as old as human history. ${ }^{35}$

In the twentieth century which has just past, history noticed three 
great war, they were World War I (1914-1918), World War II (1939-1945), and Cold War (1950-1990). The latter, the Cold War, happened of the bipolar new political order, focusing to two adversary ideological blocks: capitalist democratic Western and communist Eastern block. The earlier block is dominated by the super power United State of America, and the latter by Sovyet Union. The two super power countries competed each other to get influence on the Third World or developing countries. ${ }^{36}$

Observing the progress of "culture" of violence being apprehensive about, --in the past, in the present time as well as the possibility in the future time that will threaten the future of human beings - Parliament with its declaration invited all human beings to stop violence and replace with the culture of non-violence and respect life. By this invitation, it is expected there will be a peaceful life.

Another example of world crises is the exhausted of natural resources and environmental deprivation that are caused by modernization with its industrialization. United State of America can be referred as the example in this case. As Schumacher pointed out, USA as the most developed industrial country, with only 5.6 percent of world population, for its industrial needs this country requires about 40 percent of world primary resources. ${ }^{37}$ It showed what a greedy the modern industry is in using natural resources, and at once showed that modern industry is not efficient: need much requirement with a less output. The fact showed that America would be able to progress its economic development as far as it is able to exploit world's natural resources.

Besides the exploitation of natural resources, environmental damage is another problem of world. The disposal of solid, liquid and gas waste into soil, river, sea and open air have caused negative effects on environment. Soil pollution caused the less of soil ability to support agriculture cultivation. River pollution caused fishes and other living creatures in the river die. While air pollution effected to health retardation. The outstanding effect of this pollution is the decrease of natural resources capability to support long tern development processes. Even Club of Rome, on 1970s, in The Limits of Growth, as cited by Ismid Hadad, predicted the coming of disaster that will threaten all human being in the time scale of not more than 100 years later, if the tend of economic, population, and raw material uses as well as natural resources exploitation, environmental pollution are let to be there, like we find today. ${ }^{38}$

Being realized of the unrestrainable natural resources exploitation as well as environmental damage, the Parliament explicitly stated that such an 
action is uncivilized. Then, the Parliament invited all human beings to be responsible ---especially the next generation--- of this earth and cosmos. Domination on nature must be stopped, on the contrary harmonious living with nature must be developed. It is expected that by this invitation the future human life will be sustainable and the welfare guarranted, not adversely, getting disaster and destroy.

Another not less frightening crises is poverty suffered by millions human beings. Millions people have no job, exploited by low wage, and millions forced to be homeless drifter, with possibilities of giving up future hope. These all, according to the Parliament are caused by injustice of capitalistic- economic world order.

The fail of capitalistic system with its free-market institutions in implementing social justice in fact had become a critical discourse among scholars, one of whom is John Rawls, an American contemporary philosopher, well known with $A$ Theory of Justice. ${ }^{39}$ Indeed Rawls agree with the concept of Adam Smith, pioneer of liberal capitalism, on self-expression of human being in accordance to free choice and effort they did. Rawls agree with Smith too that free market served the best possibility for expression of one self. Nevertheless, Rawls looked that the mechanism of free market is fail to function well.. ${ }^{40}$ For that reason, free market affected in injustice. According to Rawls, the most outstanding injustice in a given freedom is that this system allows wealth division influenced inappropriately by accident natural and social conditions, which is arbitrary in the perspective of moral. ${ }^{41}$

Considering that tragedy of poverty, starvation, unemployment, suffered by millions human beings are caused by injustice order of world's economic, so for solving the tragedy the Parliament invited all human beings to devote them selves to the culture of solidarity and build a justice economic order. The Parliament clearly stated "there will not be any peace without a global ethic".

Such described some examples of global crises that human beings facing, which is in turn frightened of threatening human beings future. Declaration of a global ethic, thus, is an effort to offer solutions for that crise, by referring to ethics values came from religions.

From the description above, it can be concluded that a global ethic that was declared by the Parliament of the World's Religions has the significance in creating peaceful world. Peaceful world meaning here is not only negative peace but also positive peace. 
In the field of peace studies, peace was distinguished between negative and positive peace. Generally, scholars defined negative peace as the absence of violence. Galtung, for example defined negative peace as "the absence of organized violence between such major human groups as nations, but also between racial and ethnic groups because of magnitude that can be reached by internal wars". ${ }^{2}$ In another book, simply he defined it as "the absence of violence all kinds". ${ }^{43}$ Fisher et al. described negative peace that he mentioned it also cold peace as "absence of war". ${ }^{44}$ Similar to some definitions above, Hiks defined negative peace as the absence of direct (personal) violence, violence directed by one person on to another as in the case of assault, torture, terrorism, or war. ${ }^{45}$ Birgit Brock-Utne, as mentioned by Snyder, developed Galtung's concept, distinguishing betwen organized and unorganized violence, which highlighted violence against women, such as rape, and other gender-specific forms of discrimination. ${ }^{46}$

While positive peace commonly understood as more than the absence of violence, it also $\mathrm{X}^{47}$ Related to $\mathrm{X}$ in positive peace, schoolars explained it variably. Galtung for example mentioned it as "a pattern of corporation and integration between major human groups". "Hiks indicated it as involving co-operation and non-violent social change, aimed at creating more equitable and just structures in society. ${ }^{49}$ While Fisher et al. identified it as encompasses all aspects of the good society that we might envisage for ourselves: universal rights, economical wellbeing, ecological balance and other core values. ${ }^{50}$

From the definitions on peace as described above, both in negative and positive meaning, it can be stated that there are some values that must be there in peace; they are non-violence, economic welfare, social justice, ecological balance, ${ }^{51}$ and equality, especially gender equality. Even It is these values that are promoted by the Declaration of a Global Ethic. As discussed beforehand, there are four values that become the commitment of the declaration; they are, commitment to a culture of non-violence and respect for life, commitment to a culture of solidarity and a just economic order, commitment to a culture of tolerance and a life of truthfully, and commitment to a culture of equal rights and partnership between men and women. Thus, it is clear the significance of the declaration of a global ethic in attempting the formation of peaceful world.

\section{CLOSING REMARKS: THE NEED OF GLOBAL DISSEMINATION FOR A GLOBAL ETHIC}


As stated before, The Parliament of the World's Religions believed that global ethic they declared, which based on ethic values within religions, can be applied to resolve global crises attacking this world and threatening the future of human beings. Although the ethic values can not give any direct solution on all the so complicated world problems, but that values are convinced to be able to lay moral foundation for a better individual as well as global order, which in turn will be able to create a peaceful world. That is why The Parliament stated explicitly that "There will be no better global order without global ethic". 52

The problem is: Is there any prospect to implement the declaration? No one knows the exact answer for the question. Obviously now global ethic has become a programmatic term. However, it is clear either that the Declaration toward a Global Ethic has not become the realization of global ethic yet. This kind of declaration is not an objective. It is only a means for certain objectives: for resolving any global world crises and for compelling inter-religious peace. This inter religious peace constitutes a very important thing, because as Hans Kung stated, "No world peace without religious peace". ${ }^{33}$ Therefore, whatever came up from it will be depended on all people in this world. ${ }^{54}$

Since declared at 1993 up to now, the existence of global ethic has been 26 years. It seemed that what become the objectives of the declaration of global ethic has not been realized. Violence in the most apparent kind: war and terror happened every where. Poverty still suffered millions people in this world. Destruction of natural and ecologic resources is getting worse. Gender inequality still became a big problem for some nations. In other words, global ethic has not significantly contributed in structuring peaceful world. Indeed, it is so exaggerated to lay the burden to resolve the global crises as well as to structure the peaceful world on global ethic. But, claiming that global ethic has not any importance at all in resolving global crises as well as in structuring peaceful world is something unreasonable. Multi-approach is needed. One of the approaches is the need of "global effort to change how people think and act", ${ }^{55}$ and declaration of global ethic can be seen as one of the effort.

That a global ethic which is believed by the declarators, to be able to resolve global crises as well as to structure the peaceful world but in fact has not been optimal, so there must be a lack of effort toward the objectives optimally, to make a global ethic as behavior guideline for global 
community. A global ethic with ethic values within has not been disseminated well to global community. A global ethic is still privileged, and only in academic discourse.

As mentioned in the former part, religious leader in the Parliament of the World's Religions, who declared global ethic, are leaders representing their own religions individually, not members of religious hierarchy or formal delegation of their leader or board. It is understandable from this fact that if a global ethic declared by the Parliament of the World's Religions is not easy to disseminate amongs religious leader within religious organizations, this is more on grass root level of religious community.

Meanwhile a global ethic is still more in academic sphere, could be seen from Hans Kung advises in disseminating the declaration of a global ethic. Hans Kung stated that in order to make a global ethic not to terminate only on declaring but also implementing, the scholar from any religions are demanded to make steps forward that declaration by designing a global ethic project seen from their own religions, emphasizing on three points below: firstly, to what extent the declaration rooted in their tradition; secondly, to what extent their traditions are related to other ethic tradition; and thirdly, to what extent their tradition contributed to a global ethic. ${ }^{56}$

The three points that Hans Kung suggested is important to consider by academicians from religions for strengthening the existence of a global ethic itself as ethic concept expected to approve by all religious community. Nevertheless, that is not enough to make a global ethic can be approved by religious community, moreover till the level that can become a guideline of action. The most important to do is intensive dissemination for religious community. At least, there are two stages of dissemination that must to do: firstly is for the leaders of religious organizations at all level; international, national, as well as local; and secondly for religious community at large.

The importance of disseminating a global ethic to religious leaders is based on two reasons. In one hand is that because a global ethic itself is religious ethic; the ethic which is based on ethic values attached to religions, and at the other hand because of the importance of religious organization leaders in religious community. Within religious community, religious leaders are model. However, this is not an easy thing to do, because even though a global ethic drawn from religions, but it is a humanistic and inclusive ethic. While, it must be recognized that there are so many exclusive religious leaders. This is a challenge. Applying hard work the big challenge can be managed. The point making sure that a global ethic will be approved by the leaders of religious organizations is that because factually 
all religions, theologically aspired the world peace, ${ }^{57}$ a value that the global ethic stated as its objection.

One example which can be mentioned here is the basic principles for world peace in Islamic teaching, as mentioned by Kumar, namely: (1) All human beings are members of one family having Adam and Eve as their parents. (2). Different tribes and nations are not only for the sake of knowing each from other. None is by birth superior or inferior. Of course, the noblest is one who is the most righteous. (3) There is no superiority or preference for any particular nation black or white, north or south, east or west all are equals. (4) Life, honor and property of all is equally respected and to be protected. (5) Freedom of faith is guaarranted for all nations and individuals. (6) Islam is against colonialism, racialism, and aggresive-nationalism. (7) Islam is against the supremacy of man on man all are slaves of the Almighty alone. (8) All international treaties and agreements have to be respected in letter and spirit. (9) No exploitation of any individual or society is allowed. (10) Justice is the guiding principle for all human behaviors and relations. ${ }^{58}$ Those some of the basic principles for world peace in Islamic teaching are the principles in accordance to the values tried to effort by global ethic

Just the global ethic is successfully disseminated to the leaders of religious organization at all levels, so the following step, dissemination to religious adherents, will be easier. It is because religious adherents usually follow their leaders. The meaning of religious adherents here are all religious adherents, whatever their background, gender, age, education, job, and their positions in their community. Surely, the backgrounds of religious community needed a various strategies to disseminate a global ethic. A global ethic can be disseminated by religious leaders through speech and sermon in mosque, church, temple, Budism monastery, and other buildings for worship. A global ethic can be disseminated through peace education in schools as well as universities. Within this processes, there is no need to mention a global ethic explicitely. The most important here is that the values contained within the global ethic can reach to the religious adherents, and in turn can become a guideline of their activities in their life. One thing need to realize is that dissemination of global ethic is a dissemination of value. That is why, this effort is not an easy task, and it do need a long time, as long as the age of humanity itself.

To close this paper, it is needed to review that the discussion on peaceful future world, weather it will direct toward a peaceful world, or 
global crises will still facing, or even worse, is hypothetic: it can be proven as true or untrue. At this point, in fact we are in decisive position. Which one more important, the prediction truth or anticipation power? As soon as all the inclination in that prediction is executed, so the prediction will be proven. In this context, prediction is like a command. This is the meaning of prediction has the principle of self-fulfilling, something absent before, impossible to be present, but after predicted so become present afterward. In the other side, prediction can be having the meaning of prohibition, which principally is same to command, with adverse effects. Because it has been predicted, so there are so many efforts to avoid anything predicted, and the prediction is unproven. This is another principle of prediction, self-defeating. Prediction is unproven because it is predicted before. ${ }^{59}$

There has been so much prediction on world future. There was Huntington hypothesis stated that there will be a clash of civilization, especially between Western and Islam in the era of Post Cold War and Globalization, which constitutes the continuation of world conflict happened before. There were some predictions, like of Kaplan, Entzensberger, or Club of Rome, as mentioned earlier. All can be true but can be false, depended on the anticipation that human do as the actor of history.

The Declaration toward a global ethic can be seen as anticipation to the possibilities of a horrifying world future, as forecasted by the futurist. The declaration is expected to be able to resolve global crises and to design a peaceful world. Weather the declaration can be implemented or not, it is all depended much on the commitment to make it reality; and it is depended much on us, as human community occupied in this world.[]

\section{Catatan Akhir:}

${ }^{1}$ Modernism is a movement of thought a and world view which originately inspired by Descartes, strengthened by Enlightenment (Aufklarung), and then made itself everlasting till twentieth century throgh the domination of science and capitalism. See I. Bambang Sugiharto. Postmodernisme: Tantangan bagi Filsafat (Yogyakarta: Kanisius 1996) p. 29

${ }^{2}$ See Alwi Shihab. Islam Inklusif: Menuju Sikap Terbuka dalam Beragama, (Bandung: Mizan, 1998) p. 50.

${ }^{3}$ Ibid., p. 51.

${ }^{4}$ See Hans Kung. "Towards a World Ethic of World Religions: Fundamental Questions of Present-Day Ethics in a Global Context" in Concilium 2, 1990, pp. 104-5.

${ }^{5}$ See Budhy Munawar-Rahman. "Kata Pengantar" in Komaruddin Hidayat and Wahyuni Nafis. Agama Masa Depan: Perspektif Filsafat Perennial (Jakarta: Paramadina, 1995) pp. xv-xvi. 
${ }^{6}$ E.F. Schumacher. Keluar dari Kemelut: sebuah Peta Pemikiran Baru (A guide for the Perplexed) transl.. Mochtar Pabottinggi (Jakarta: LP3ES, 1981) p. 160.

${ }^{7}$ See Syamsul Arifin, et.al.. Spiritualitas Islam dan Peradaban Masa Depan (Yogyakarta: Sipress, 1996) p. 34.

${ }^{8}$ See M. Amin Abdullah. Studi Agama: Normativitas atau Historisitas (Yogyakarta: Pustaka Pelajar, 1996) p. 47.

${ }^{9}$ See in Herdi SRS and Ulil Abshor-Abdalla. "Meruntuhkan Hegemoni Tafsir, Menghidupkan Kembali Teks" in Ulumul Qur'an, No. 3, Vol. V, 1994, pp. 84-7.

${ }^{10}$ See John Naisbitt and Patricia Aburdene. Megatrend 2000: Ten Directions for the 1990's (New York: William Morrow and Company, Inc., 1990) on the tittle "Religious Revival of the Third Millennium", pp. 270-97.

${ }^{11}$ See Syamsul Arifin. "Beragama untuk Konflik?", in Republika, Saturday 9 January 1999, p.6.

${ }^{12}$ See Nurcholish Madjid. "Beberapa Renungan Kehidupan Keagamaan untuk Generasi Mendatang” in Ulumul Qur'an, No. I, Vol. IV, 1993, pp. 7-8.

${ }^{13}$ Compare to Komaruddin Hidayat and Wahyuni Nafis. Agama Masa Depan: Perspektif Filsafat Perennial (Jakarta: Paramadina, 1995) pp. 116-8.

${ }^{14}$ See Th. Sumartana. "Kata Pengantar" in Hans Kung and Karl-Josef Kuschel. Etik Global (A Global Ethic: The Declaration of the Parliament of the World's Religions), transl. Ahmad Murtajib (Yogyakarta: Pustaka Pelajar, 2000) pp. xvi-xvii.

${ }^{15}$ The Parliament of the World's Religions. "Declaration Toward a Global Ethic" in Hans Kung and Karl-Josef Kuschel (ed.). A Global Ethic: The Declaration of the Parliament of the World's Religions (New York: Continuum, 1993) p. 18.

${ }^{16}$ Ibid., p. 21.

${ }^{17}$ Hans Kung. "The History, Significance and Method of the Declaration Toward a Global Ethic" in Hans Kung and Karl-Josef Kuschel (ed.). A Global Ethic: The Declaration of the Parliament of the World's Religions (New York: Continuum, 1993) p. 45.

${ }^{18}$ Karl-Josef Kuschel. "The Parliament of the World's Religions, 1893-1993" in Hans Kung and Karl-Josef Kuschel (ed.). A Global Ethic: The Declaration of the Parliament of the World's Religions (New York: Continuum, 1993) pp. 77-8.

${ }^{19}$ Hans Kung. "The History, Significance and Method of the Declaration Toward a Global Ethic"..., p. 45.

${ }^{20}$ Karl-Josef Kuschel. “The Parliament of the World's Religions, 1893-1993”. ..pp. 80-1.

${ }^{21}$ See Hans Kung. . "The History, Significance and Method of the Declaration Toward a Global Ethic"..., pp. 45-53.

${ }^{22}$ See Th. Sumartana. "Kata Pengantar"..., p. xvi-xvii.

${ }^{23}$ The Parliament. "Declaration..., p. 17.

${ }^{24}$ Ibid., p. 18. 
${ }^{25}$ Compare to St. Sunardi. "Dialog: Cara Baru Beragama (Sumbangan Hans Kung bagi Dialog antar Agama)" in Abdurrahman Wahid et al.. Dialog: Kritik dan Identitas Agama (Yogyakarta: DIAN dan Pustaka Pelajar, 1994) p. 80.

${ }^{26}$ See Hans Kung. Global Responsibility: In Search of a New World Ethic (London: SCM Press, 1991) p 71.

${ }^{27}$ Ibid., p. 21.

${ }^{28} \mathrm{Ibid}$. Every religion has its own theoretical and conceptual framework in the field of ethics. But according to Hans Kung, the initiator of a global ethic, ethics is not a matter of theoretical; and conceptual variability. Ethics is a matter of living practices, a living problems like we feel. Ethics is related to our attitude toward the good and the bad, what should to do and should not to do. Religions has their own theoretical and conceptual framework; and that is the fact which must be considered to make a concencus, but not to prohibit the principle thing for a global as the expression of global responsibility. We can approve one point and do some things, although each religion has a its own theoretical and conceptual term of reference. See St. Sunardi. "Dialog: Cara Baru Beragama (Sumbangan Hans Kung bagi Dialog antar Agama)”..., pp. 81.

${ }^{29}$ See Hans Kung. Global Responsibility..., pp. 89-93.

${ }^{30}$ The Parliament. "Declaration..., pp. 21.

${ }^{31}$ Hans Kung. "The History, Significance and Method of the Declaration Toward a Global Ethic"..., pp. 55-7.

${ }^{32}$ Ibid., pp. 58-9..

${ }^{33}$ The Parliament. "Declaration...,pp. 24-34.

${ }^{34}$ Ibid., pp. 35-6.

${ }^{35}$ See Djoko Suryo. "Mengungkap Gejala Kekerasan dalam Sejarah Manusia" in Syifaul Arifin et al. (ed.). Melawan Kekerasan Tanpa Kekerasan (Yogyakarta: Pustaka Pelajar, 2000) p. 32.

${ }^{36}$ Ibid., pp. 53-57. Discussion on Cold War deeply, see Eric Hobsbawm. The Age of Extremes: A History of the World, 1914-1991 (New York: Vintage Books, 1996) pp. $225-56$.

${ }^{37}$ See E.F. Schumacher. Kecil Itu Indah (Small is Beautiful), transl. S. Supomo (Jakarta: LP3ES, 1981) p. 113.

${ }^{38}$ Ismid Hadad, "Persoalan dan Perkembangan Pemikiran dalam Teori Pembangunan" in Prisma, No. 1, Januari 1980, Tahun IX, p. 33.

${ }^{39}$ See A. Sonny Keraf. Pasar Bebas, Keadilan, dan Peran Pemerintah: Telaah atas Etika Politik Ekonomi Adam Smith (Yogyakarta: Kanisius, 1996) pp. 262-72.

${ }^{40}$ Rawls. A Theory of Justice..., p. 72.

${ }^{41}$ Ibid.

${ }^{42}$ Johan Galtung. Peace: Research, Education, Action (Copenhagen: Christian Ejlers, 1975) p. 29.

${ }^{43}$ Johan Galtung. Peace by Peaceful Means: Peace and Conflict, Development and Civilization (Oslo: International Peace Research Insitute, 1996) p. 31. 
${ }^{44}$ Simon Fisher et al. Working with Conflict: Skill and Strategies for Action (London: Zed Book s Ltd., 2000) p. 12.

${ }^{45}$ David Hiks. "Understanding the Field" in David Hiks (ed.). Education for Peace: Issues, Principles, and Practice in the Classroom (London: Routledge, 1988) p. 6.

${ }^{46}$ Anna Snyder. "Gender Relation and Conflict Transformation among Refugee Women" in Dennis J.D. Sandole (ed.). Handbook of Conflict Analysis and Resolustion (Oxon: Routledge, 2009) p. 46.

${ }^{47}$ Johan Galtung. "Toward a Conflictology: the Quest for Transdisciplinarity" in Dennis J.D. Sandole (ed.). Handbook of Conflict Analysis and Resolustion (Oxon: Routledge, 2009) p. 515.

${ }^{48}$ Galtung. Peace: Research, Education, Action..., p. 29.

${ }^{49}$ Hiks. "Understanding the Field"..., p. 6.

${ }^{50}$ Fisher et al. Working with Conflict..., p. 12.

${ }^{51}$ Hiks. "Understanding the Field"..., p. 7.

${ }^{52}$ The Parliament. "Declaration..., p. 21.

${ }^{53}$ See Hans Kung. Global Responsibility: In Search of a New World Ethic (London: SCM Press, 1991) p. 71.

${ }^{54}$ Hans Kung. "The History, Significance and Method of the Declaration Toward a Global Ethic"..., p. 75-6.

${ }^{55}$ UNESCO. Transdisciplinary Project: Toward a Culture of Peace, in http://www.unesco.org/cpp/uk/projects/infoe.html, accessed 20 July 2009.

${ }^{56}$ Hans Kung. "The History, Significance and Method of the Declaration Toward a Global Ethic"..., p. 73.

${ }^{57}$ See Ravindra Kumar. Religion and World Peace (Meerut: Sara Publications, 1998).

${ }^{58}$ Ibid., pp. 60-1.

${ }^{59}$ See Daniel Dhakidae. “Anatomi Ramalan” in Prisma, No. 1, January 1984, p. 2.

\section{DAFTAR PUSTAKA}

Abdalla, Ulil Abshor and Herdi SRS, "Meruntuhkan Hegemoni Tafsir, Menghidupkan Kembali Teks" in Ulumul Qur'an, No. 3, Vol. V, 1994.

Abdullah, M, Amin. Studi Agama: Normativitas atau Historisitas, (Yogyakarta: Pustaka Pelajar, 1996). 
Ahmed, Akbar S. and Hastings Donnan, "Islam in the Age of Postmodernity" in Akbar S. Ahmed and Hastings Donnan. Islam, Globalization and Postmodernity, (London: Routledge, 1994).

Arifin, Syamsul, et.al., Spiritualitas Islam dan Peradaban Masa Depan, (Yogyakarta: Sipress, 1996).

Arifin, Syamsul, “Beragama untuk Konflik?”, in Republika, Saturday 9 January 1999.

Dhakidae, Daniel, “Anatomi Ramalan” in Prisma, No. 1, January 1984.

Falikowski, Anthony F., Moral Philosophy: Theories, Skiil, and Applications, (New Jersey: Prentice Hall, 1990).

Fisher, Simon et al.,Working with Conflict: Skill and Strategies for Action, (London: Zed Book s Ltd., 2000).

Galtung, Johan, Peace: Research, Education, Action, (Copenhagen: Christian Ejlers, 1975).

Galtung, Johan, Peace by Peaceful Means: Peace and Conflict, Development and Civilization, (Oslo: International Peace Research Insitute, 1996).

Galtung, Johan, "Toward a Conflictology: the Quest for Transdisciplinary" in Dennis J.D. Sandole (ed.). Handbook of Conflict Analysis and Resolustion, (Oxon: Routledge, 2009).

Hadad, Ismid Hadad, "Persoalan dan Perkembangan Pemikiran dalam Teori Pembangunan" in Prisma, No. 1, Januari 1980.

Hidayat, Komaruddin and Wahyuni Nafis, Agama Masa Depan: Perspektif Filsafat Perennial, (Jakarta: Paramadina, 1995).

Hiks, David, "Understanding the Field" in David Hiks (ed.), Education for Peace: Issues, Principles, and Practice in the Classroom, (London: Routledge, 1988).

Hobsbawm, Eric, The Age of Extremes: A History of the World, 19141991, (New York: Vintage Books, 1996).

Huntington, Samuel P., "The Clash of Civilization?", Foreign Affairs, Summer 1993.

Keraf, A. Sonny, Pasar Bebas, Keadilan, dan Peran Pemerintah: Telaah atas Etika Politik Ekonomi Adam Smith, (Yogyakarta: Kanisius, 1996).

Kumar, Ravindra, Religion and World Peace, (Meerut: Sara Publications, 1998). 
Kung, Hans, "Towards a World Ethic of World Religions: Fundamental Questions of Present-Day Ethics in a Global Context" in Concilium 2, 1990.

Kung, Hans, Global Responsibility: In Search of a New World Ethic, (London: SCM Press, 1991).

Kung, Hans, "The History, Significance and Method of the Declaration Toward a Global Ethic" in Hans Kung and Karl-Josef Kuschel (ed.). A Global Ethic: The Declaration of the Parliament of the World's Religions, (New York: Continuum, 1993).

Kuschel, Karl-Josef, “The Parliament of the World's Religions, 18931993" in Hans Kung and Karl-Josef Kuschel (ed.). A Global Ethic: The Declaration of the Parliament of the World's Religions, (New York: Continuum, 1993).

Madjid, Nurcholish, "Beberapa Renungan Kehidupan Keagamaan untuk Generasi Mendatang" in Ulumul Qur'an, No. I, Vol. IV, Tahun 1993.

Magill, Frank N. (ed.), Masterpieces of World Philosophy, New York: Harper Collins Publisher, 1990.

Naisbitt, John and Patricia Aburdene, Megatrend 2000: Ten Directions for the 1990's, (New York: William Morrow and Company, Inc., 1990).

Rahman, Budhy Munawar, "Kata Pengantar" in Komaruddin Hidayat and Wahyuni Nafis. Agama Masa Depan: Perspektif Filsafat Perennial, (Jakarta: Paramadina, 1995).

Rawls, John. A Theory of Justice, (Cambridge, Massachusetts: The Belknap Press of Harvard University Press, 1997).

Robertson, Roland, Globalization: Social Theory and Global Culture, (London: Sage Publications, 1994).

Runes, Dagobert D. (ed.), Dictionary of Philosophy, (Totowa New Jersey: Littlefield Adams \& Co., 1974).

Schneewind, J. B, "Modern Moral Philosophy" in Peter Singer (ed.). A Companion to Ethics, (Malden, Massachusetts: Blackwell Publishersm, 1997).

Schumacher, E.F., Keluar dari Kemelut: sebuah Peta Pemikiran Baru (A guide for the Perplexed) transl.. Mochtar Pabottinggi, (Jakarta: LP3ES, 1981).

Senghass, Dieter, The Clash within Civilizations: Coming to Terms with Cultural Conflicts, (London and New York: Routledge, 2002). 
Shihab, Alwi, Islam Inklusif: Menuju Sikap Terbuka dalam Beragama, Bandung: Mizan, 1998.

Snyder, Anna, "Gender Relation and Conflict Transformation among Refugee Women" in Dennis J.D. Sandole (ed.). Handbook of Conflict Analysis and Resolustion, Oxon: Routledge, 2009.

Sugiharto, I. Bambang. Postmodernisme: Tantangan bagi Filsafat, Yogyakarta: Kanisius, 1996.

Sumartana, Th, "Kata Pengantar" in Hans Kung and Karl-Josef Kuschel. Etik Global (A Global Ethic: The Declaration of the Parliament of the World's Religions), transl. Ahmad Murtajib, Yogyakarta: Pustaka Pelajar, 2000.

Sunardi, St, "Dialog: Cara Baru Beragama (Sumbangan Hans Kung bagi Dialog antar Agama)" in Abdurrahman Wahid et al.. Dialog: Kritik dan Identitas Agama, Yogyakarta: DIAN and Pustaka Pelajar, 1994.

Suryo, Djoko, "Mengungkap Gejala Kekerasan dalam Sejarah Manusia" in Syifaul Arifin et al. (ed.). Melawan Kekerasan Tanpa Kekerasan, Yogyakarta: Pustaka Pelajar, 2000).

The Parliament of the World's Religions, "Declaration Toward a Global Ethic" in Hans Kung and Karl-Josef Kuschel (ed.). A Global Ethic: The Declaration of the Parliament of the World's Religions, New York: Continuum, 1993.

UNESCO,Transdisciplinary Project: Toward a Culture of Peace, in http://www.unesco.org/cpp/uk/projects/infoe.html, accessed 20 July 2009.[] 